African Research Review An International Multidisciplinary Journal, Ethiopia

Vol. 10(1), Serial No.40, January, 2016: 104-115

ISSN 1994-9057 (Print)

ISSN 2070--0083 (Online)

Doi: http://dx.doi.org/10.4314/afrrev.v10i1.9

\title{
European Influence in Ijo-Itsekiri Relations in Nigeria
}

\author{
Erezene, Henchard B. \\ Department of History and Diplomacy, \\ Niger Delta University, Wilberforce Island, \\ P.M.B. 071, Yenagoa, \\ Bayelsa State, Nigeria \\ Phone No: +2348033820868 \\ E-mail: Ereacademics@Gmail.Com
}

\begin{abstract}
There is currently an uneasy calm in the Ijo-Itsekiri area of the Western Niger Delta. The two groups have intermarried, and had lived together for centuries. But towards the end of the last century, the two groups clashed, ostensibly over the relocation of the headquarters of the then newly created Warri South (later Warri South-West) Local Government Area from Ogbe-Ijoh (an Ijo town) to Ogidigben (an Itsekiri town). During the crisis, the two groups had employed all types of dangerous and sophisticated weapons against each other. This development had made many well-meaning persons to wonder if there were longstanding grievances between them. This article underscores the fact that there was, indeed, deep-noted bitterness between the two groups, dating back to the period of European contact with Nigeria from the $15^{\text {th }}$ Century. the hostilities started with the introduction of new forms of trade, religion, education, government etc. because of space, this article concentrates on three major areas, namely, trade, education, and land acquisition and ownership. The article is produced mainly from written sources.
\end{abstract}




\section{Introduction}

The Europeans came to Nigeria and other parts of Africa, as explorers, missionaries, traders and colonial administrators. In order to accomplish the purposes for which they came, they did a lot of things which profoundly affected the traditional ways of life of the local people.

In the Warri area of the Western Niger Delta region of Nigeria, the activities of the Europeans greatly influenced the relations between the Ijo neighbours in the area. The general consensus is that the two groups had lived peacefully together in precolonial times, and that it was the advent of the Europeans with their new forms of trade, religions, education, government and so on that strained the hitherto cordial relations between them. This is in agreement with this position. The idea, however, is not to further divide the people or be turn them against the Europeans, but to enable them see the roots of their present misunderstandings, so as to make them see if they could make amends, and live peacefully together again.

In order to do some justice to the topic, some of the issues (factors) that were introduced by the Europeans that had caused problems between the two groups are examined one after the other. All of the issues cannot be taken in just one article. We have therefore concentrated on trade, education, and land acquisition and ownership matters.

By the $19^{\text {th }}$ century, some of the people of Nigeria have had about three hundred years of contact with the Europeans mainly through trade (Orugbani, 2005). In those early days of trade relations between the Europeans and the local people, first in slaves and later in agricultural products, the Europeans were contented with anchoring at the coast and waiting for the Nigerian middlemen to go into the hinterland and bring them the commodities they wanted (Ikime, 1982). This simple arrangement, as is well known, was the result of physical geographical barriers, language problems and the Europeans' fear of the malaria-breeding mosquitoes in the interior. There was also the opposition mounted by the rules and peoples of coastal states. Because of these hindrances, the Europeans traders had no direct access to the production areas of the commodities they needed until about the 1880s.

Another important development in their early commercial (and even missionary) activities was that the Europeans were for obvious reasons of security and peace, more attracted to centres of centralised political authority. Thus, in the Western Niger Delta, the first places the Europeans made their trading centers were the port of Ughoton (Gwato), which was the nearest river port to the capital of the ancient Benin Empire, and Ode-Itsekiri, the ancestral headquarters of the Itsekiri Kingdom (Alagoa, 1970). The trade at Ughoton was controlled by the Oba of Benin while that at OdeItsekiri was under the authority of the Olu of Itsekiri. By the end of the 18th century, however, European trading vessels could no longer get to Ode-Itsekiri; they rather 
anchored at the lower reaches of the Benin River (Lloyd, 1969). This was because of the treacherous and shallow bay of the Forcados River, which linked the town.

In order to continue to enjoy trade with the European, the Itsekiri migrated to found new settlements along the Benin and Escravos Rivers. By this time, the Gbaramatu and Egbema Ijo sub-groups had also arrived in these places. It was, however, the Itsekiri that had a better control of the trade as their settlements were more strategically located at the mouths of the rivers. The Ijo who were sandwiched between Itsekiri settlements became a problem to the trade on the two rivers. They preyed on ships and looted goods. Both the European and Itsekiri traders, therefore, dreaded them. The Ijo at times blocked the whole river, preventing movement up or down. In 1692, the Olu of Warri was said to have written a letter to Father Monteleone in Benin. In the letter, he complained:

Matters here are in such a state that everybody is suffering to some extent, the reason is that the Ijos are stopping us from going to Benin and my subjects are unable to cultivate their farms, which is a great hardship (Ryder, 1977, p. 146)

This clearly explains the frequent mention of the Ijo as pirates in the early European records. John Barbot (1732, p. 356 cited in Alagoa, 2005, p. 26) has, for example, referred to the Ijo of the Benin River as a people river as a people "who lived altogether on plunder and piracy on the rivers".

The Itsekiri acting as the most influential middlemen, especially in the era of the legitimate trade in agricultural products, procured palm-oil and other commodities from the Urhobo, Isoko and other upland groups and sold them directly to the Europeans at the coast. The pattern of trade was that the Itsekiri merchants collected goods such as cloth, guns, gun powder, glass wares, mirrors, rugs, spirits, beads, plates and so on from the Europeans on trust, and distributed them to credit-worthy persons in the Benin River settlements who would mobilise big canoes to go to the hinterland markets. The trust goods were further distributed, in the markets, to local producers who supplied the commodities the Europeans needed (Sagay, n.d.).

The inability of the local producers at times to supply the required commodities often to raids in which individuals were sometimes handed over as pawns to the Itsekiri creditors. Failure on the part of the Itsekiri merchants to deliver the required goods to a European trader who had advanced trust goods to them resulted, many times, in the seizure of consignments meant for other Europeans, which often put the Itsekiri trader in tight corners. This practice, which was popularly known a "chopping", offended the Itsekiri middlemen, resulting sometimes in conflicts between them and the Europeans (Ikime, 1982). 
It must also be explained that some of the European traders never wanted the Itsekiri merchants and middlemen to fully pay up their trusts so as to make it difficult for them to trade with other Europeans (Orugbami, 2005). To break this monopoly, European traders who had newly arrived, offered higher prices for oil and other commodities they needed. Some Itsekiri merchants were naturally tempted to do business with these NEW ARRIVALS. This provided another opportunity for the Europeans who had advanced trust goods to them to seize their goods.

On the other side, the local traders who had faithfully discharged their trust obligations but their European customers thought otherwise. Such miscalculations often led to hot disagreements and even trade boycotts. These ugly occurrences, notwithstanding, the Itsekiri made money and prospered as middlemen.

Apart from the favourable location which enabled them to effectively play the role of middlemen in the trade in the trade relations between the Europeans on the coast and the local people in the hinterland, it was one of them that always occupied the exalted office of the "Governor of the River" (that is the Benin River which was one of the greatest centres of European trade in West Africa during the $19^{\text {th }}$ century). The Governor (rendered as Gofune by local people) was the chief customs officer and was responsible for collecting the traditional custom duties, comey, on the river. It was also his exclusive function to fix prices for new goods introduced by the Europeans as well as the local products the Europeans desired to buy (Sagay, n.d.). He was thus a very powerful officer, looked upon for favours by both the Europeans and the local people. He allowed those he wanted to trade on the river to do so, including the Europeans.

Originally, the Governor was the Olu's Revenue Collector or Minister of Finance. The olu, therefore, traditionally made his appointment. This important procedure was unfortunately destroyed when Olu Akengbuwa died in 1848, and there was no immediate successor.

Akengbuwa's two sons, by his Ijo wife (Ebiminiere), Omateye and Ejo, one of whom would have succeeded him died, according to Itsekiri traditions, in quick succession, and in mysterious circumstances. More unfortunate was the fact that none of the sons of the late brothers was old enough to take charge of affairs. Things were, therefore left in the hands of the royal slaves of Omateye's household to handle. These slaves, Ebrimoni, Okorodesu (Okoro Idosu), Ugbodundun and others, suspecting foul play in the death of their master and his younger brother, ensured that none of the other sons of Olu Akengbuwa ascended the throne. They took over control and installed their master's half-sister, Idolu, (alias Iye) to run the affairs of the Itsekiri Kingdom. This action of the slaves is what some writers like Elizabeth Isichei (1978) have referred to as a slave revolt in Warri. It needs to be explained that the action of the slaves was not to take advantage of the confusion to free themselves. It was rather a display of 
solidarity to ensure that the proper thing was done in their late master's household or estate.

But the action of the slaves could not really settle the problem; Idolu could not be crowned as Olu because the Itsekiri national constitution forbade a woman from occupying the throne. Thus, started a long period of interregnum, which lasted for eighty-eight years, from 1848 to 1936.

The British, like other European groups had always desired in their commercial and missionary activities, as we have earlier stated, to deal with centralised political authorities. Consequently, in the absence of an Olu, John Beecroft persuaded the Itsekiri to consider the option of electing or selecting a non-royal head to take charge of the affairs of the people. This situation led to the resuscitation of the "Governor of the River" which was occupied consecutively by Idiare (1851 - 1870), Olomu (1879$1883)$ and Nana (1884 - 1894). These men became very wealthy and wielded power and influence not only on the Benin River but also in the hinterland markets. Obaro Ikime (1977) has informed us, for example, of how Olomu and his son, Nana waged wars against people of Igun, Eku and Abraka, right in the heart of Urhoboland in 1880s. In fact, with no Olu on the throne, the office of the Governor of the River became extremely influential.

The case of Nana was, in a way, special/ his mother, Memese was an Urhobo from Effurun. Apart from that, he married many Urhobo wives: Ejemutohwo and Emebiren from Agbarho, Ikogho from Udu; and Agbemeta and Ughoro from Abraka (Ikime, 1977). He was thus at home in Urhoboland both as a son and a son-in-law which made business connections easy for him. In fact, Nana and his predecessors in office became a source of national pride to the Itsekiri. From one of his sources, Ikime (1971) states that Nana could boast of 20,000 war boys, 100 war canoes and over 200 trade canoes.

Apart from occupying the office of the Governor of the River and acquiring wealth, therefrom, the Itsekiri also made money from guiding new captains of ships to Warri. In the earlier period when European ships sailed through the Forcados Rivers to Ode-Itsekiri, the Ijo were in charge of business (Preboyee, 2005). But from the beginning of the $19^{\text {th }}$ century when the ships began to anchor as the mouths of Escravos and Benin Rivers (especially the latter), the Itsekiri took over. These advantages clearly placed them ahead of their Ijo, and even Urhobo neighbours in terms of wealth and social status. With their wealth and relatively higher social status, as a people who dealt directly with the Europeans, the Itsekiri started to exhibit pride; looking down on others. This partly led to the rise of anti-Itsekiri sentiments in those days in Warri and its environs. Uptil today, the Ijo in particular, see the Itsekiri as a proud and selfish people who do not seem to care about the feelings of others (Erezene, 2008). 


\section{Introduction of Western Education}

It is well known that western education came to Nigeria and other parts of Africa mainly as a by-product of European commercial and missionary activities. In both ventures, the Europeans discovered that their efforts to accomplish desired goals were limited by geographical and language barriers, their susceptibility to malaria and the fact they were too few to go round. For them to succeed, they soon legalised that they would need the services of the local people. As traders, they needed them as tally clerks and as missionaries, they needed them as catechists, interpreters and lay preachers.

For the local people to be able to function in these positions, they had to be given some kind of education, no matter how rudimentary its form or content was. For the missionaries, education afforded them yet another advantage; it was a simple and relative inexpensive way of catching the people young. The European missionaries had realised that Africans (Nigerians) were "die hard" in their traditional beliefs. They, therefore, reasoned that if they were to make any head-way in their desire to evangelise and convert people to Christ, they would have to get them young - begin with the children. In fact, it is believed in some quarters that the non-adoption of educational programmes was mainly responsible for the failure of early attempts at converting people to the Christian faith in Nigeria (Afigbo, 1973).

In Warri area of the Western Niger Delta, the Itsekiri were the earliest people to acquire western education through their contacts with the early Portuguese missionaries. Prince Eyeomasan (alias Atonrongboye) who later reigned as $\mathrm{Olu}$ Sebastian was allowed by his father, Olu Esigie, to be converted and baptised as a way of assuring the Christian missionaries as Ode-Itsekiri that he was not against their new religion. He was said to have received European education through Portuguese assistance. His successor, Atuwase, studied in Coimbra University in Portugal for eleven years and obtained a degree, which made him the first graduate Olu of Itsekiri. He was baptised as Dom Domindo, and later married a Portuguese lady of royal birth who bore him a mulatto son, Antonio Domingo. This mulatto who succeeded his father and reigned between 1643 and 1654, is said to have written a letter to the Pope in 1652, requesting him to send missionaries to work in his kingdom (Ayomike, 1990). Another Christian Olu, Akengboye (baptised as Dom Agostinho) was also said to have written another letter to the King of Portugal, asking him to send him more priest and images of Christian saints. The implication of this was that these Olu were literate even before western education was formerly introduced in Warri and its environs. It is said that Olu Ogbejeoye (alias Luigir), developed so much interest in education that he sent his three sons to be trained in Sao Tome, an Island off the Nigerian coast.

The early acquisition of western education by the Itsekiri through their contacts with the Portuguese became even a source of pride to them. It boosted their social status 
vis-à-vis their Ijo and even Urhobo neighbours. By the time economic and political rivalries blossomed in the Warri area in the $19^{\text {th }}$ and $20^{\text {th }}$ centuries following European "divide and rule" tactics to get the best of the resources of the land for themselves, the Itsekiri were not only well equipped to utilise their advantages in education to the fullest, but also saw themselves as a somewhat superior group, though small in population. In his book, The Ijaw in Warri (1990), J.O.S. Ayomike has vividly reported an incident purported to have occurred when an Itsekiri lawyer, Barrister S.E. Aganbi who had trained in the United Kingdom returned in 1964. On seeing her son, he stated, the mother who had led the procession to welcome him from Lagos at the Sapele beach ran out and embraced him, saying: "I am happy you have come in time. A little more delay would have been disastrous. Already Ijaw at the Sapele market are speaking English." The above statement is a clear reflection of how the Itsekiri rated the Ijo around them. Having no comparative educational attainment at that time, the Itsekiri saw them as a primitive and backward people.

In a more recent publication at page 42 of the Vanguard Newspaper of 13 June, 2003 captioned 'Attention: The Danjuma Committee. The Warri Crisis - Facts in figures', a renowned Urhobo Pharmacist, Chief J.E. Ukueku, has stated that by 1925, the first lawyer had emerged in Warri, by name, Asifor Egbe. He was an Itsekiri and his son, Barrister Webber Egbe was the only one honoured as Queen's Counsel (Q.C.) in the whole of the then Mid-West Region. But as late as 1944, according to the colonial documents available, the Ijo of Gbaramatu had no single educated man to be sent as a delegate to the meetings of the Native Administration's Financial Committee, and there was no one in view (WP. 180/1). It was in 1958 that Barrister E.K. Eseoru (an IduwiniIjo) returned from England and set up legal practice in Warri. The point to note, is that the early acquisition of western education made the Itsekiri to feel superior and proud. This made their immediate neighbours, the Ijo to develop more anti-Itsekiri sentiments.

\section{Land Acquisition and Ownership Problems}

The trust system, which operated mostly during the overseas trade in palm oil and other agricultural products, had a major disadvantage for the European traders in that they had to wait for long periods of time before getting their consignments from the Nigerian middlemen who went to the hinterland markets to bring what they needed to them at the coast. The individual European merchants, therefore, pooled resources together to form companies, which appointed agents in their areas of operation. In the Benin River area, which had become one of the greatest centres of trade in the whole of West Africa at the time, these agents were appointed mainly in the various Itsekiri communities. And before long, these companies began to establish factories on some of the creeks, which they knew to be safe.

From the 1830s, many of these factories owned by Messrs Horsfall, Harrison and Co., Louch and Co. etc flourished on the Benin River and at Warri. Ifediora (2002) 
has stated that even before the 1930s, up to eleven European firms were already operating in the Province of Warri with at least eleven stations in Warri itself.

To establish a factor was not an easy task for the Europeans. First, a suitable site had to be found. Once this task was accomplished, the European merchants had to negotiate with the local authorities for the purchase or lease of the plot of land concerned. In Itsekiri, the Olu held all land in trust of the people and so, he alone, could sell or lease land to anybody. But in practice, however, it was the Governor (Gofune) who performed this function on behalf of the Olu and his people. For the Ijo, the situation was different. Land was owned by the community, and could not be leased or sold by one individual, no matter his social or political status.

By 1894, the last Governor of the River, Chief Nana Olomu, had been dealt with by the British. Caught by the circumstances of his office, Nana fell out of favour with the British imperialist and was accused of being a slave dealer, using his agents in Urhoboland to terrorise the people and obstructing free trade, etc. To get at him, Ebrohimi (his headquarters) was bombarded. Nana escaped but later gave himself up and was deported first to Calabar and later to Accra.

The removal of Nana, which was expected to guarantee free trade and ensure peace in the hinterland markets, backfired. Trade suffered, as there was nobody to be held responsible for the misbehaviour of the Itsekiri and other traders on the Benin River. In fact, some European traders like John Holt started to call for his re-instatement (Sagay, n.d.). And so, something urgent needed to be done by the European traders and the imperial administration of the Niger Coast Protectorate to fill the vacuum created by Nana's removal and deportation.

In 1891, a native court was established to take care of the affairs of the Itsekiri but the power and influence of Nana had rendered it ineffective. This court was resuscitated as a kind of native authority along the Benin River and in 1896, minor courts were opened in which the local chiefs sat without direct interference from European officers. The clear implication of this development was that the British officers of the Niger Coast Protectorate has started to see the relevance of using traditional institutions in running native affairs.

At that time, there were some Itsekiri chiefs who had demonstrated enough loyalty to the British to be 'employed in responsible positions' (Sagay, n.d.: 145). Rated very high among these loyal chiefs was Dogho (Dore) Numa. He had, as early as 1891, provided Vice-Consul Gallwey with a crew when he wanted to visit Lagos. Nana had provided Gallwey with a canoe but was not prepared to allow any of his slaves to undertake the journey for fear of their running away at Lagos.

In 1894, Dogho again for personal reasons, sided with the British to deal with Nana. His grouse was that Nana had triumphed over his father in 1884 to become the 
Governor of the River. He was, therefore, seen as a loyal supporter of Her Britannic Majesty's Government. And so, when it was decided to get someone with good knowledge of the Benin River to restore law and order in the creeks, he clearly stood out to be the man and was thus appointed as political agent in 1896 (Ikimi, 1982; Sagay, n.d.) for the Benin River and later for the whole Warri area.

As political agent, he mobilised to further please his masters. Covered by the provisions of the Public Land Acquisition Ordinance of 1903, which was clearly designed by the British to make their acquisition of land from the local people easy, Dogho signed the leases, which gave them (the British) parcels of land to build their trading firms and consulate offices in 1906, 1908 and 1911 (Ikime, 1977, 1982; Onaibe, 1992). The ordinance states, according to Ikime $(1977 ; 189)$ that 'where lands required for public purposes were the property of a native community, the Head Chief of such community may sell and convey same for an estate in fee simple, notwithstanding any native law and custom to the contrary.' This provision gave Chief Dogho Numa the authority to do what he did as the 'Head Chief' of Warri recognised by the British. At that time, many Itsekiri individuals, families and communities vehemently opposed the actions of Chief Dogho Numa and saw him as an impostor (Ifediora, 2005). He was, in fact, taken to court by the Pessu family of Warri and the Ugborodo community at the mouth of the Escravos River. According to Honourable Oboko Bello (oral interview), the Ugborodo case was decided in his favour while he lost the former. But when the Ijo and Urhobo started to protest the 'illegal' lease of their lands to government by this man, some of these same Itsekiri individuals, families and communities turned round to argue that Chief Dogho leased the affected parcels of land as a representative of the Olu (Lloyd, 1969; Ayomike, 1990, Sagay, n.d.). The substance of their argument was that all lands in Warri belonged to the Olu and the Itsekiri. This claim is not only hotly contested by the Ijo of Ogbe-Ijoh but by the Urhobo of Agbarha (Agbassa) and Okere as well. It must be noted that in 1906, 1908 and 1911 when the said parcels of land were leased to the British, there was no Olu on the Itsekiri throne. There was also no Governor (Gofune) who could have done it on behalf of the Olu as allowed by the Itsekiri traditional constitution. The leases were made during the period of interregnum when there was no Olu. It is even more interesting to note that J.O.E. Sagay, a fullblooded Itsekiri has acknowledged in his book Warri Kingdom (n.d.) that the parcel of land Chief Dogho leased to the British in 1908 was Ogbe-Ijoh land. This land, which measured some 90 acres, was leased to the Colonial Government for 99 years at $£ 60$ starting from 18 July, 1908 Sagay's claim that this parcel of land belonged to OgbeIjoh community is not only corroborated by the Ogbe-Ijoh people but also by the renowned historian, Professor Obaro Ikime in his recent contribution to the publication of the Urhobo Historical Society, The Urhobo People (2003). The Ogbe-Ijoh who resisted the lease were force out of the land when Consul Seton James Esquire burnt 
down two quarters of the original Ogbe-Ijoh town, Arotenghan and Perebiri (WP. 180/1).

That the Ijo owned land in Warri is further proved in some subleases after the major ones by Chief Dogho Numa. For example, a 1944 subleases of land to Messrs G.B. Ollivant Limited made by one F.M. Ikomi still bore Ogbe-Ijoh, Warri (WP. 175/1). Uptil now, the Ijo are still struggling to regain their ownership of these parcels of land. They have not only notified the Itsekiri who currently own properties on these parcels of land that they (Ijo) are the original owners and must be so recognised but have also signalled government that the lease periods have expired and that they were patiently waiting to take their lands back.

On their part, the Itsekiri argue that the Ijo have no land in Warri. They assert that all parcels of land in Warri the Ijo lay claims to had long been litigated upon and judgment entered in their (Itsekiri) favour. These court judgment are, however, held in contempt by the Ijo and Urhobo. They dismiss them as political judgments; not based on historical facts or sound legal arguments. During the colonial period, they argue, 'law and jurisprudence were not paramount' (Obioma 2004). What was important was the interest and desires of the colonial power, and because the Itsekiri establishment represented by Chief Dogbo Numa, was doing their bidding, the British colonial judges had no qualms deciding cases in their favour. At present, the Ijo claim that the whole waterfront running from Miller Waterside (Old NPA) to Pessu, including Alder's Town, Robert Road, the former Government Reservation Area (GRA) etc. belong to them. These areas formed part of the nucleus from which the present Warri Township developed. They, therefore, strongly feel that they are stakeholders in Warri politics and development, and cannot be pushed aside by any other group. They also refuse to accept that their towns and villages situated along the Escravos and Benin rivers are located on Itsekiri land.

\section{Conclusion}

It is clear from the discussions above, that the activities of the Europeans in the Warri area of the Western Niger Delta region of Nigeria greatly influenced the relations between the Ijo and Itsekiri. These activities turned the two groups against each. It must however be acknowledged that the problems between the two groups were mainly caused by pride and insincerity mostly on the part of the Itsekiri. Having gained upperhand in trade and politics in the Warri area, they started to look down on their neighbours. This development naturally led to anti-Itsekiri sentiments by the Ijo and even the Urhobo in the area. 
AFRREV, 10 (1), S/NO 40, JANUARY, 2016

\section{References}

Afikpo, A.E. (1973). An investigation of the relationship between Christian missions and seminar authorities in south eastern Nigerian from colonial times. Oduma, $1(1), 15-20$.

Alagoa, E.J. (1970). Long distance trade and states in the Niger Delta. Journal of African History, XI (3), 319-329.

Alagoa, E.J. (2005). A history of the Niger Delta: An historical interpretation of Ijo oral tradition. Port Harcourt: Onyoma Research Publications.

Ayonike, J.O.S. (1990). The Ijaw in Warri: A Study in Ethnography. Benin City: Mayomi Publishers.

Erezene, H.B. (2008). Living together in the Niger Delta: A historical study of IjoItsekiri relations in the nineteenth and twentieth centuries. Ph.D Dissertation, University of Port Harcourt, Port Harcourt, Nigeria.

Ifediora, A.O. (2002). European mercantile institutions and the growth of Warri: (19001960). Agbor Journal of Arts and Social Sciences, 1(1), 76 - 81.

Ifediora, A. O. (2005). Arresting urban crisis conflicts in Nigeria: The case of Warri and Environs. In Orubu; O.O., Mordi, E.N. \& Ifediora, A.O. (eds.) The challenge of democracy and development in the twenty-first century. Benin City: Ethiope Publishing Corporation, 74-93.

Ikime, O. (1971). Merchant prince of the Niger Delta. Ibadan: Longman.

Ikime, O. (1977). Niger delta rivalry: Itsekiri- Urhobo relations and the European presence 1884 - 1936. Ibadan: Longman.

Ikime, O. (1982). The fall of Nigeria: The British conquest. London: Heinemann Educational Books Ltd.

Ikime, O. (2003). History of the Urhobo. In Otite, O. (ed.). The Urhobo people (2nd Edition). Ibadan: Shaneson C.I. Ltd, $43-68$.

Isichei, E. (1978). History of West Africa since 1800. London and Basinstoke: Macmillan.

Lloyd, P.C. (1969). Introduction to Second Edition (By William Moore). In history of Itsekiri. London: Frank Case and Company Ltd, i-xii.

National Archives Ibadan. Mr. E.M. Ikomi - Sublease of Land to Messrs G. B. Olivant Ltd, Ogbe - Ijoh, Warri. File No. WP. 175/1.

National Archives Ibadan. Gbaramatu Clan Intelligence Report. File No. WP. 180/1.

Copyright (C IAARR, 2007-2016: www.afrrevjo.net

Indexed African Journals Online: www.ajo.info 
Obioma, D.A. (2004). British treaties and ownership of Warri: A response to J.O.S. Ayomike's claims. In Ekeh, P.P. (ed), Warri and British colonial rule in the Western Niger Delta. Bufallo: Urhobo Historical Society, 165 - 186.

Oboko, B., 49, Oral Interview, Warri, 7 March, 2005.

Onaibe, J. (1992). Warri: The making of Nigeria's Middle East. Ughelli.

Orugbani, A. (2005). Nigeria since the 19th Century. Port Harcourt: Paragraphics.

Preboye, I.C. (2005). The core Delta: Iduwini clan. Ibadan: Rural Development Nig. Ltd.

Ryder, A. (1977). Benin and the Europeans 1485 - 1897. London: Heinemann Educational Books Ltd.

Sagay, J.O. E. (n.d.). The Warri kingdom. Sapele: Progress Publishers.

Ukueku, J.E. (2003). Attention: The Danjuma committee, the Warri crisis - Facts and Figures. Vanguard Newspaper, Friday, 13 June. 